\title{
The influence of school principals' leadership behaviour and act of fairness on innovative work behaviours amongst teachers
}

\begin{tabular}{|c|c|}
\hline \multicolumn{2}{|c|}{$\begin{array}{l}\text { Authors: } \\
\text { Peter P. Khaola }{ }^{1} \text { (1) } \\
\text { Francis A. Oni }{ }^{1} \text { 『 }\end{array}$} \\
\hline \multicolumn{2}{|c|}{$\begin{array}{l}\text { Affiliations: } \\
{ }^{1} \text { Department of Business } \\
\text { Administration, Faculty Social } \\
\text { Sciences, The National } \\
\text { University of Lesotho, Roma, } \\
\text { Lesotho }\end{array}$} \\
\hline \multicolumn{2}{|c|}{$\begin{array}{l}\text { Corresponding author: } \\
\text { Peter Khaola, } \\
\text { peterkhaola@gmail.com }\end{array}$} \\
\hline \multicolumn{2}{|c|}{$\begin{array}{l}\text { Dates: } \\
\text { Received: } 13 \text { June } 2020 \\
\text { Accepted: } 27 \text { Oct. } 2020 \\
\text { Published: } 08 \text { Dec. } 2020\end{array}$} \\
\hline \multicolumn{2}{|c|}{$\begin{array}{l}\text { How to cite this article: } \\
\text { Khaola, P.P., \& Oni, F.A. (2020). } \\
\text { The influence of school } \\
\text { principals' leadership } \\
\text { behaviour and act of fairness } \\
\text { on innovative work behaviours } \\
\text { amongst teachers. SA } \\
\text { Journal of Human Resource } \\
\text { Management/SA Tydskrif } \\
\text { vir Menslikehulpbronbestuur, } \\
\text { 18(0), a1417. https://doi. } \\
\text { org/10.4102/sajhrm.v18i0. } \\
1417\end{array}$} \\
\hline \multicolumn{2}{|c|}{$\begin{array}{l}\text { Copyright: } \\
\text { (c) 2020. The Authors. } \\
\text { Licensee: AOSIS. This wc } \\
\text { is licensed under the } \\
\text { Creative Commons } \\
\text { Attribution License. }\end{array}$} \\
\hline \multicolumn{2}{|l|}{ Read online: } \\
\hline 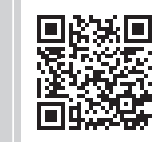 & $\begin{array}{l}\text { Scan this QR } \\
\text { code with your } \\
\text { smart phone or } \\
\text { mobile device } \\
\text { to read online. }\end{array}$ \\
\hline
\end{tabular}

Background: Although innovative work behaviours (IWBs) of teachers are important for individual school's effectiveness and national economic sustainability, only fewer studies on leader-related behaviours drive IWBs of teachers in public schools in Lesotho.

Research purpose: Drawing from the theories of leadership, affective commitment, social exchange and justice, the study examined the influence of school principals' leadership styles and fairness on achieving IWBs amongst teachers.

Motivation for the study: The teachers' IWB amongst schools plays a key role in endorsing and producing innovative and adaptable future-oriented human capital. However, only scant research is available on the role of school leadership behaviour on teachers' IWB in public schools. This happens despite the agreement amongst scholars and practitioners that critical thinking imparted by innovative teachers is a valuable source of creative labour force, a critical component for sustained national economic growth.

Research approach/design and method: Data collected from 210 teachers in Lesotho (response rate $=71 \%$ ) were analysed by means of correlation and multiple regression analyses to examine the hypothesised relationships.

Research findings: The results indicated that the general supervisor-support factor (consisting of the perception of leadership and fairness of a principal) had a positive and significant effect on IWBs of teachers. Contrary to expectations, the affective commitment of teachers to their schools did not relate significantly to their IWBs.

Practical/managerial implications: The article discusses these findings, suggests their theoretical and practical implications and outlines the prospects for future research on factors that may influence IWBs of teachers in schools. In order to improve teachers' IWBs, this paper recommends that school principals be provided with training on how to articulate a compelling vision; coach, mentor and develop their subordinates; challenge them to think creatively; treat them with honesty and respect; and follow school policies, procedures and regulations all the time.

Contribution/value add: This study adds to the scant literature regarding the role of school principals in nurturing IWBs of teachers in public schools.

Keywords: affective commitment; creativity; fairness; innovative work behaviour; leadership.

\section{Introduction}

Literature shows that, as primary centres and suppliers of knowledge and skills, schools depend largely on leadership to provide strategic direction, a professional community, self-renewal and innovation in learning and teaching (Berkovich \& Bogler, 2019; Blase \& Blase, 2000; Ismail, Don, Husin, \& Khalid, 2018). Even though many streams of research continue to enrich our knowledge of sources of affiliative extra-role behaviours in schools (Burns \& DiPaola, 2013; Srivastava, 2017; Srivastava \& Dhar, 2019), little is known about the drivers of change-oriented extra-role behaviours such as innovative work behaviours (IWBs). Thus, compared to non-school organisations, research on IWBs in schools is still emerging and is yet to reach its full potential. This is surprising because innovative teachers play a critical role in building innovative labour force for national economic growth competitiveness (Henning et al., 2018; Huang, Lee, \& Yang, 2019; Reilly, Lilly, Bramwell, \& Kronish, 2011). 
Drawing from literatures on leadership and IWBs in the private sector, the current study hypothesises that teachers' affective commitment and perceptions of their school principal leadership and fairness will significantly influence their IWBs. Affective commitment refers to emotional attachment of employees to their organisation and is an attitudinal variable (Meyer \& Allen, 1991). Leadership is the process by which leaders influence their followers to achieve shared goals (Berkovich \& Bogler, 2019), and fairness broadly captures employee perceptions about the fairness with which outcomes are distributed; processes and procedures are followed, and the treatment they obtain from their supervisors and organisations. Leadership and fairness are closely related because they centre on the acts of the leaders (Khaola \& Rambe, 2020). The terms 'fairness' and 'justice' are often used interchangeably in the literature. IWBs are change-oriented behaviours that are predominantly extra-role and intentional in nature and involve the creation and implementation of novel and useful ideas (Khaola \& Coldwell, 2017b).

As indicated by Bramwell, Reilly, Lilly, Kronish and Chennabathni (2011) and reiterated by Daly, Mosyjowski and Seifert (2019), it bears a remarking that, unless teachers are creative and innovative, it is difficult to 'imagine' innovative teaching in schools. It hampers skills development base, especially for the youth, which is needed for the fast-changing world and on the edge of the fourth industrial revolution. Thus, more research studies on teachers' IWBs are necessary because the aftermath of critical thinking imparted by innovative teachers is treasured in schools as a potential source of innovative labour force for sustainable national economic growth (Henning et al., 2018; Reilly et al., 2011). Consequently, IWBs amongst teachers will help in driving the strategic goal of a country's national development.

The third strategic goal of the National Strategic Development Plan (NSDP) in Lesotho is to enhance the skill base, technology adoption and foundation for innovation. Even though the NSDP was launched in 2012, the recent Global Competitiveness Report (GCR, 2018) still ranks Lesotho at 110 of 140 countries on pillar 6: skills. The ranking on one component that builds this pillar, 'critical thinking in teaching', places the country lower at 117 of 140 countries. Even more disturbing, the report ranks the country at 132 of 140 countries on pillar 12: innovation capacity. In general, recent GCRs imply that concerted efforts are needed to improve the skill base of young people in Lesotho, especially in information technology and communication (ICT), innovation and technical and vocation education and training (TVET) sectors. As shown in Figure 1, on a scale of $0-7$, Lesotho has been under-performing on innovation-related scores for the past 11 years.

\section{Research purpose and objectives}

The purpose of this article is to examine whether affective commitment, leadership and acts of fairness influence IWBs of teachers in schools. Specifically, the article examines the influence of the school principal's leadership and fairness and teachers' affective commitment on IWBs.

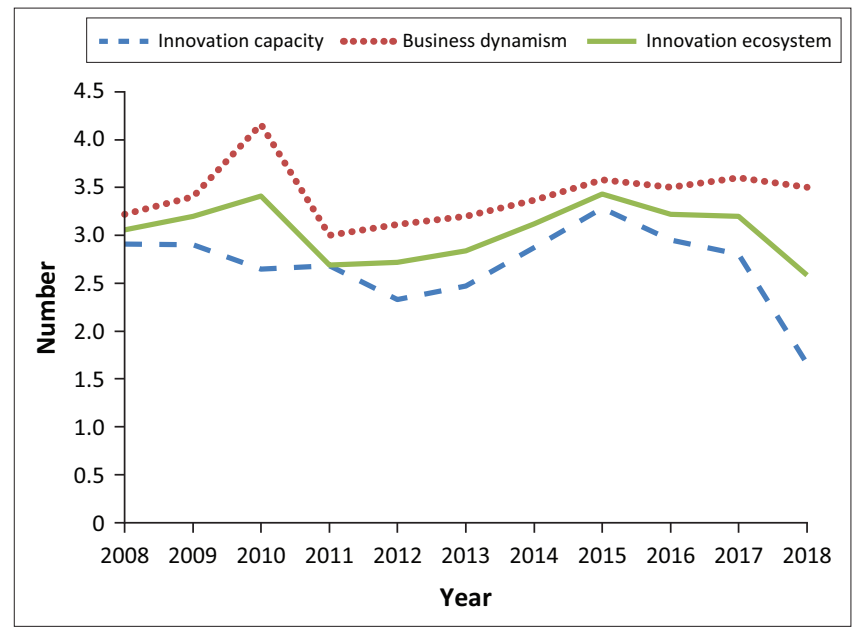

Source: Global Competitiveness Report. (2018). The Global Competitiveness Report 2018: A project of World Economic Forum. In K. Schwab (Ed.). Geneva: World Economic Forum. Retrieved from http://www3.weforum.org/docs/GCR2018/05FullReport/ TheGlobalCompetitivenessReport2018.pdf

Note: Global Competitiveness Reports, 2008-2018. The scores ranged from 0 to 7 points from 2008 to 2017, but they ranged from 0 to 100 points in 2018. The scores for 2018 were recalculated to a scale ranging from 0 to 7 points.

FIGURE 1: Global competitiveness report on Lesotho.

\section{Significance of the study}

To achieve the main purpose, four overlapping contributions to the IWB literature in schools are made. Firstly, even though researchers have started to heed calls of improving the innovation literature in the public sector (Lubienski \& Perry, 2019; Torfing, 2019), little is known about the factors that influence creative practices of teachers in public schools (Henning et al., 2018; Reilly et al., 2011). More specifically, there has been a plea to further research into the influence of the leader's demeanours on teacher's behaviour (Blase \& Blase, 2000; Dash \& Vohra, 2019; Ismail \& Mydin, 2019). Secondly, the article attempts to clarify the relative importance of attitudes such as affective commitment against the leaderrelated situational factors such as leadership and fairness on creativity and innovation. Such attention is warranted in studying a multi-stage and complex concept such as IWB (De Jong \& Hartog, 2010; Liu, 2019; Liu, Chow, Zhang, \& Huang, 2019; Stojcic, Hashi, \& Orlic, 2018). Thirdly, the article examines the impact of transformational leadership on IWBs. The question of how and whether leaders influence IWBs of employees, particularly creative practices of teachers, has to date not received the attention it deserves. Past studies have demonstrated inconsistent relationships between transformational leadership and innovative behaviour in non-school settings (Ismail \& Mydin, 2019). Fourthly, the focus on teachers and teaching in the developing countries, particularly in the sub-Saharan Africa, provides an opportunity to examine the role of leaders' behaviours on IWBs for generalisability to under-researched settings. In this case, Lesotho is used as an example. It is important to state that this study is particularly important in Lesotho where the Ministry of Education and Training (MoET, 2014) has introduced a new integrated school curriculum which aims at developing the 'thinking skills' and flexibility of learners. Mixed reactions have trailed this development to warrant further interrogations of its viability and sustainability. In light of the foregoing, Raselimo and Mahao (2015) have 
identified paradoxes and contradictions in the new curriculum. This article argues that effective school principal leadership and their acts of fairness are essential for motivating teachers, which will in turn result in teachers' creativity and innovation.

The rest of this article is organised as follows: the next section focuses on the development of hypotheses, followed by the presentation of research methodology and results in the third and fourth sections, respectively. The discussion of the results and conclusions are presented in the final section of the article.

\section{Literature review and development of hypotheses Leadership and innovative work behaviours}

There has been a growing interest on the leadership and of those in charge of schools (principals), especially on how their leadership behaviours influence the creativity and innovation of the teachers under their respective tutelages (Bednall, Rafferty, Shipton, Sanders, \& Jackson, 2018; Gil, RodrigoMoya, \& Morcillo-Bellido, 2018; Marks \& Printy, 2003). Leadership has generally been defined as a process by which one influences others to achieve shared goals (Berkovich \& Bogler, 2019). Many cited definitions of IWB have the strong influence of the seminal work of Janssen (2000, 2004). The author defined IWB as 'the intentional creation, introduction and application of new ideas within a work role, group or organisation, in order to benefit role performance, the group, or the organisation' (Janssen, 2000, p. 288, 2004, p. 202).

From an individual's perspective, IWB can be seen as the creation, introduction and application of new ideas in the organisation to support organisational performance (Ghani, Hussin, \& Jusoff, 2009). Teachers with IWB display creativity and are innovative at work, generate new ideas and are able to provide constructive outcomes for their schools. These definitions and associated measurement scales have been used successfully amongst teachers. For instance, Bakker and Xanthopoulou (2013) used the multifactor leadership questionnaire (MLQ) and Janssen's (2000) scale to measure leadership and creativity, respectively. The IWBs of teachers comprise their creativity (production of novel and useful ideas) and innovation (championing and implementation of ideas; Janssen, 2000; Lu, Bartol, Venkataramani, Zheng, \& Liu, 2019; Scott \& Bruce, 1994; Stojcic et al., 2018).

The demands in our knowledge society are indeed increasing both for students and for their teachers (Klaeijsen, Vermeulen, \& Martens, 2017); thus, IWB is vital in order to keep abreast of society's development. Likewise, new advancements and new knowledge require IWB because the teaching styles adopted by teachers have a bearing on students' selfdetermination towards learning and motivation (AwangHashim, Thaliah, \& Kaur, 2017). Moreover, schools ought to serve as a starting point and showcase more IWB to influence society at large and improve its competitiveness. After all, education promotes students' creative and innovative thinking (Usma \& Frodden, 2003). Thus, a creative and innovative teacher is the one who (1) introduces novel and useful ideas into curriculum, pedagogy and assessment; (2) supports and sponsor new developments in curriculum, pedagogy and assessment; and (3) seek new ways of implementing developments in curriculum, pedagogy and assessment.

Bass and Avolio (1995) argue that transformational leadership is a multidimensional concept with the following dimensions: charismatic role modelling (the leader's ability to inspire respect, admiration, loyalty and collective sense of mission); individualised consideration (the leader's ability to consider and understand individual follower's needs and aspirations); inspirational motivation (the leader's ability to articulate a compelling vision for the future); and intellectual stimulation (the leader's ability to challenge and stimulate followers to think about old problems in new ways).

In this regard, a transformational school principal is likely to transform personal values and self-concepts of teachers to transcend their own self-interest for the greater good of those they serve and elevate them to higher needs and aspirations. This is because transformational school principals may influence the intrinsic motivation of teachers, thereby increasing their creativity and innovation in teaching (Gumusluoglu \& Ilsev, 2009; Jensen et al., 2019; Marks \& Printy, 2003; Saboe, Taing, Way, \& Johnson, 2015). Furthermore, the social cognitive theory predicts that transformational principals would build self-efficacy and empowerment of teachers, which would in turn affect their creativity (Gumusluoglu \& Ilsev, 2009; Ninkovi , \& Kneževi Flori, 2018).

Consistent with extant theories, past studies have suggested that leadership innovation is a strong correlate of school innovation (Chou, Shen, Hsiao, \& Shen, 2019; Hughes, Lee, Tian, Newman, \& Legood, 2018). Saboe et al. (2015) found that principal transformational leadership influenced school performance through principal instructional leadership (the ability to supervise classroom instruction, coordinate school curriculum and monitor students' progress through assessment). Thus, integrated leadership consisting of transformational leadership (emphasising change, ideas and innovation) and instructional leadership (emphasising direct elements involved in teaching and learning) provides good basis for performance of students and schools. Khaola and Coldwell (2017a) found that constructive leadership (the combination of transformational and contingent reward forms of leadership) was positively related to IWBs of teachers in Lesotho.

Despite the existing compelling theoretical and practical evidence, sometimes the effects of transformational leadership on creativity and innovation, including that of teachers, have not been consistent (Jensen et al., 2019; Khaola \& Coldwell, 2017b, 2019a, 2019b; Marks \& Printy, 2003; Mumford \& Lucuanan, 2004), suggesting the need for further 
investigation in other settings and contexts. The weight of evidence suggests, however, that there is a positive relationship between transformational leadership and IWB (Khaola \& Coldwell, 2017a, 2019a, 2019b). The following directional hypothesis can, therefore, be examined:

H1: There is a positive relationship between principal's transformational leadership and teachers' IWB.

\section{Fairness and innovative work behaviours}

Perception of fairness is one of the situational factors that should conceptually influence IWBs. It refers to one's perceptions of fairness in (1) outcome distributions, (2) processes and procedures that regulate the outcome decisions and (3) interpersonal treatment and interactions related to how the supervisor treats employees (Colquitt et al., 2013). Consistent with fairness literature, school principals are likely to be perceived as fair if they distribute school resources equitably to teachers, allow teachers a voice in decisionmaking, apply rules and regulations consistently across teachers, take responsibility for mistakes and correct them and take actions based on the evidence rather than innuendo (Burns \& DiPaola, 2013; Khaola \& Coldwell, 2017b).

Social exchange theory predicts that teachers who perceive fair treatment from agents of schools (principals) are likely to reciprocate by engaging in IWBs. Furthermore, fairness is closely linked with employee voice; and consistent with cognitive evaluation theory (Deci \& Ryan, 1985; Kaufman, 2015), treating employees with respect and providing them with information is also likely to signal a supportive and psychologically safe environment necessary for risk-taking and intrinsic motivation, both are critical for creative performance (Anderson, Poto ik, \& Zhou, 2014). Whilst these theories make sense, limited research are available on the relationship between employee perception of fairness and IWBs (Khazanchi \& Masterson, 2011), especially in schools (Burns \& DiPaola, 2013). Even though emerging evidence indicates that the direct effects of fairness on IWB are equivocal (Zhou \& Hoever, 2014), some studies have found significant relationships between these constructs. Khaola and Coldwell (2017b) found the positive relationship between the teachers' organisational justice and IWB. Similarly, Khazanchi and Masterson (2011) found the positive relationship between interactional justice and creativity. Along similar lines, Burns and DiPaola (2013) found the significant relationship between the teachers' perception of fairness and the concept closely related to IWB-organisational citizenship behaviour. Even though more work needs to be performed on examining the relationship between fairness and IWBs, existing literature (albeit limited) takes us to the following directional hypothesis:

H2: There is a positive relationship between the teachers' perception of fairness and their IWBs.

\section{Affective commitment and innovative work behaviours}

Affective commitment has been described as one's emotional attachment to one's organisation (Jiang \& Johnson, 2018;
Mercurio, 2015; Meyer \& Allen, 1991). Teachers generally possess a strong attachment to their jobs and professions (DiPaola \& Tschannen-Moran, 2001; Somech, 2016). According to some scholars, teachers are personally and emotionally involved in their jobs because their work involves nurturance, warmth, love and caring for others (O'Connor, 2008; Walker \& Gleaves, 2016). Following this view, it was expected that the teachers' affective commitment would be positively related to their IWBs, principally because social exchange theory holds that affective commitment is an attitudinal indicator of the extent to which employees perceive themselves to be in high-quality social exchange relationships with their organisations (Colquitt et al., 2013). Thus, teachers may express their affective commitment through engagement in IWBs. This notwithstanding, the relationship between affective commitment and IWB may sometimes be tenuous, the reason being that the traditional attitudes such as affective commitment may have weak impact on change-oriented behaviours such as IWB as employees feel strong attachment to the status quo and less motivation to change (Marinova, Peng, Lorinkova, Van Dyne, \& Chiaburu, 2015). Furthermore, because teachers are committed to their professions (O'Connor, 2008; Walker \& Gleaves, 2016), there may be little differences between their levels of commitment, thus producing little impact on IWB (the problem of ceiling effect). There is also evidence that teachers may possess multiple commitment mindsets, which may produce complex pattern of outcomes (Meyer, Morin, Stanley, \& Maltin, 2019). However, because affective commitment is the social exchange indicator of reciprocity in the form of proactivity (Colquitt et al., 2013), it can be hypothesised as follows:

H3: The teachers' affective commitment is positively related to their IWBs.

\section{Research design Sample and procedures}

The sample consisted of 110 teachers who attended part-time classes for their bachelor of education (primary) degree at the public university in Lesotho, and a further 100 additional teachers recruited from eight different high schools around the capital city of Lesotho.

Participants were requested to fill self-administered questionnaires and return them to the researcher in their natural setting. Even though a total of 149 questionnaires (71\%) were returned, only 143 questionnaires were usable. Six teachers who held positions of the school principals during the time of study were eliminated from the sample.

Of the respondent sample, $73 \%$ were females and $27 \%$ males. Thirteen per cent of the respondents were in the age group $20-30,58 \%$ in the age group $31-40,23 \%$ in the age group $41-$ 50 and $6 \%$ above 50 years of age. The participants had an average tenure of 11.28 years $(\mathrm{SD}=6.23)$. In terms of supervisory responsibilities, $74 \%$ did not have any responsibility, $22 \%$ was head of the department and only $4 \%$ held the position of the school principal. 


\section{Ethical consideration}

The participants were asked to fill the questionnaires anonymously, and confidentiality was guaranteed to all participants. The purpose of the study was communicated to all participants. Furthermore, the participants were made aware that they are free to participate in the research and non-participation would not have any negative consequences. Similarly, the questions asked were all handled with sensitivity but not compromising the quality of the study, and the information given by the participants was not in any way used to jeopardise their jobs.

\section{Measures}

To collect data, the existing scales were modified slightly to reflect the organisational environment of teachers.

Leadership: The MLQ (Bass \& Avolio, 1995) was adapted to assess the transformational leadership behaviour of supervisors (principals). Eight items were used to assess the construct. The participants were asked to assess the extent to which the listed statements described the behaviour of their supervisors (principals) on a scale ranging from 0 (not at all) to 4 (frequently if not always). A sample item was 'my school principal articulates a compelling vision for the future'. The internal reliability (Cronbach's $\alpha$ ) of the scale was 0.92 .

Fairness: Five items from the scale developed by Niehoff and Moorman (1993) were adapted to assess this construct. On a scale ranging from 1 (strongly disagree) to 5 (strongly agree), the participants were asked to assess the extent to which they agreed with the listed statements. Sample items were 'to make job decisions, the principal collects accurate and complete information' and 'I think that my level of pay is quite fair'. The internal reliability of the scale was 0.81 .

Because the factor analysis of items measuring leadership and fairness constructs produced non-interpretable factors with multiple cross-loadings, and the correlations between the constructs were high $(r=0.75$, variance inflation factor [VIF] $=$ $2)$, the items of the two constructs were averaged to create a supervisor-related factor $(\alpha=0.95)$ to avoid collinearity problem when conducting the regression analysis. Given that the sample size was small, the correlation and VIF figures were a point of concern. The addition of leadership and fairness into one common variable is supported by literature. As suggested by Van Knippenberg and Cremer (2008), even leader fairness is not typically studied in relationship to leadership, and there is an increasing recognition that leader fairness is an integral part of leadership.

Affective commitment: Five items adapted from the scale of Cook and Wall (1980) were used to measure affective commitment. On a scale ranging from 1 (strongly disagree) to 5 (strongly agree), the participants were asked to assess the extent to which they agreed with the listed statements. A sample item was 'I feel a strong sense of belonging to my school'. The internal reliability of the scale was 0.91 .
Innovative work behaviour: Nine items from the scale of Janssen (2000) were adapted to measure teacher IWB. The participants were asked to rate how often they performed the innovative activities on the scale ranging from 0 (never) to 4 (always). Sample items were 'creating original solutions for problems' and 'making important school members enthusiastic for innovative ideas'.

\section{Control variables}

Because prior research has demonstrated that IWB can be influenced by individual differences (e.g. Janssen, 2000), gender $(0=$ females and $1=$ males $)$, age $(20-30$ years $=1$; $31-40=2 ; 41-50=3$ and above 50 years $=4$ ) and tenure (in years) were included as control variables to reduce the possibility of spurious relationships based on these individual differences.

\section{Analyses}

Pearson correlation and hierarchical regression analyses based on the Statistical Package for Social Sciences (SPSS) version 20 were used to analyse data. Independent variables (leadership, fairness and affective commitment) were related to IWBs using both correlation and regression analyses.

\section{Results}

The inter-correlations of variables are shown in Table 1.

Inter-correlations in Table 1 show that transformational leadership was positively and significantly related to IWB $(r=0.29, p \leq 0.01)$, implying that higher levels of transformational leadership were accompanied by higher levels of reported IWB. Similarly, organisational justice correlated significantly with IWB $(r=0.29, p \leq 0.01)$. Contrary to the literature, affective commitment was not significantly related to IWB $(r=0.15, p \geq 0.01)$.

Although not hypothesised in this study, there were positive and significant relationships between transformational leadership and fairness $(r=0.75, p \leq 0.01)$, transformational leadership and affective commitment $(r=0.52, p \leq 0.01)$ and organisational justice and affective commitment $(r=0.48$, $p \leq 0.01)$. Based on Cohen's (1992) effect sizes, these correlations ranged from medium to high. According to Cohen (1992), there is no effect size if the value of ' $r$ ' is below 0.1 , the effect size is low if the value of $r$ is between 0.1 and 0.3 , medium if $r$ is between 0.3 and 0.5 and high if $r$ is above 0.5 .

TABLE 1: Inter-correlations of the main variables.

\begin{tabular}{lcccccc}
\hline Variable & $\mathbf{1}$ & $\mathbf{2}$ & $\mathbf{3}$ & $\mathbf{4}$ & Mean & SD \\
\hline Transformational leadership & $(0.92)$ & - & - & - & 2.41 & 1.04 \\
Fairness & $0.75 * *$ & $(0.91)$ & - & - & 3.16 & 0.86 \\
Affective commitment & $0.52 * *$ & $0.48 * *$ & $(0.81)$ & - & 3.88 & 1.10 \\
Innovative work behaviour & $0.29 * *$ & $0.32 * *$ & 0.15 & $(0.88)$ & 2.94 & 0.64 \\
\hline
\end{tabular}

Note: Cronbach's $\alpha$ are shown in parentheses.

SD, standard deviation.

*, Significant at 0.05 (two tailed); **, Significant at 0.01 (two tailed). 
TABLE 2: Hierarchical regression analyses of predictors of IWB.

\begin{tabular}{lcc}
\hline Variable & \multicolumn{2}{c}{ Innovative work behaviour } \\
\cline { 2 - 3 } & Model 1 & Model 2 \\
\hline Gender & -0.17 & -0.15 \\
Age & -0.04 & -0.08 \\
Tenure & $0.19^{*}$ & $0.16^{*}$ \\
Affective commitment & - & 0.02 \\
Leadership-related factor & - & $0.34^{* *}$ \\
Change in $R^{2}$ & 0.07 & 0.12 \\
$R^{2}$ & 0.07 & 0.19 \\
\hline
\end{tabular}

Note: Apart from change in $R^{2}$ and $R^{2}$ values, values refer to standardised $\beta$ s.

*, Significant at $0.05 ; * *$, Significant at 0.01 .

The limitation of correlation analysis is that it does not control for the spurious relationships that may be caused by other variables when examining the relationship between constructs of interest, and this may result in inflated or subdued relationships. Regression analysis was used to control for the possibility of spurious relationships that may be caused by the lack of control of related predictor variables in the correlation analysis. As indicated earlier, transformational leadership and fairness items were averaged into one overall leadership-related factor to mitigate the problems of multicollinearity. The results of regression analyses are shown in Table 2.

The results suggest that the leadership-related factor (consisting of transformational and organisational justice) was positively and significantly related to IWB $(\beta=0.34, p \leq$ $0.01)$, but affective commitment was not at all related to IWB $(\beta=0.02, p \geq 0.05)$. Thus, hypotheses 1 and 2 were confirmed, but hypothesis 3 was not confirmed.

\section{Discussion and conclusion}

Conceptually, school principal leadership should have influence on teachers' intrinsic motivation and their teaching (Ismail et al., 2018; Marks \& Printy, 2003), and consequently the quality of teaching should be reflected in the quality of learning and success for students (Nava et al., 2019). Despite the fact that creativity of teachers is considered vital for students' creative learning, only few studies focused on how the leadership behaviours of those in charge of schools influence IWBs of teachers. In the era of knowledge economy, one expects more research studies to have been carried out, mainly because creative knowledge is vital for sustainable path to economic growth (Dima, Begu, Vasilescu, \& Maassen, 2018). As centres of creation and delivery of basic knowledge, schools in Lesotho need to find ways of improving the creativity and innovation of teachers if the country is to be projected into a new growth trajectory by the future knowledgeable workforce.

The results of the current study suggest that leadership and fairness had direct effects on IWB. Whilst prior results have been mixed, or have included various mediating and moderating factors, the current findings are generally in line with some prior results (Gupta \& Singh, 2015; Oh, 2019; Rank, Nelson, Allen, \& Xu, 2009). Bednall et al. (2018) found that when transformational leadership and instructional leadership coexist in the form of integrated leadership, there is significant influence on quality of pedagogy and achievement of students. The current study suggests that a supervisor-related variable (school principal transformational leadership and fairness) has significant effects on teachers' IWBs. The two studies complement each other in the sense that they show how leadership-reference factors can motivate the (innovative) performance of teachers.

Contrary to the expectations that affective commitment would significantly influence teachers' IWBs, this study did not find significant effects of affective commitment on IWB. The reason for this is not clear, but it may have to do with the nature of affective commitment and commitment profiles of teachers. Firstly, teachers with strong affective commitment may feel strongly attached to their present situation and hence, fail to challenge the status quo (Marinova et al., 2015). Secondly, teachers have autonomy and professional focus; and according to Mumford and Lucuanan (2004), employees with this attribute do not need organisational commitment as a way of directing their creative or innovative performance. Thirdly, teachers may also be committed differentially to their schools and profession, thus creating a complex pattern of outcomes (Meyer et al., 2019). Future studies, especially qualitative ones, can examine why the commitment of teachers may not influence their creative or innovative behaviours.

\section{Managerial implications}

The results of this study have several important managerial implications. Firstly, they intimate that school principals can influence IWBs of teachers by amongst other things, by practicing positive leadership behaviours, that is, a set of actions undertaken by individuals in a position of authority and influence to motivate and develop others through mechanisms of engagement, empowerment and collaborative assignment to meaningful work (Chiok Foong Loke, 2001).

This can be effected by amongst other things; leadership training that focuses on developing transformational leadership behaviour skills. Secondly, school leaders can be trained to be fair to teachers to influence the IWB of the latter. Specifically, school principals may be trained on how to treat teachers consistently, distribute resources equitably and interact with teacher in a respectful manner. Overall the results suggest that teachers' IWBs can be improved by schools' principals who actively generate a positive social context or climate for teachers.

\section{Limitations and directions for future research}

Like many studies of this nature, the results should be interpreted with caution. Firstly, data were collected from one source using the same instrument, and the same-source and common method biases might have inflated the results. Whilst self-reports are useful for reporting perceptions and mitigating the problem of halo error (Bolino, Turnley, \& Anderson, 2016; Janssen, 2004; Kabasheva, Rudaleva, 
Bulnina, \& Askhatova, 2015), future studies can benefit by using different sources of data to mitigate the possible impact of these biases. Secondly, the cross-sectional research design used herein does not permit the examination of causality of variables. Whilst the hypotheses were based on sound theories, future studies can use experimental or longitudinal research design to determine the causality of variables. Lastly, the model may have left out some important dispositional factors. It may be that the association between predictors and IWB was being obfuscated by some underlying, unmeasured variables. In addition to the control variables included in the present study, future studies can control for variables such as one's personality, intelligence, knowledge, experience, skills and abilities.

\section{Conclusion}

The purpose of the current study was to examine whether school principal leaders, perceived acts of fairness and teachers' own affective commitment have significant effects on teachers' IWBs. The results revealed that the combination of school principal leadership and perceived acts of fairness had influence on teachers' IWBs. Against theoretical predictions, affective commitment did not have significant effects on the criterion variable. To improve IWBs of teachers, the study recommends that school principals be trained on how to acquire transformational and fairness skills. The authors of the current study hope that the results will provoke debates on the role of leadership and fairness in shaping creative teachers in public schools.

\section{Acknowledgements Competing interests}

The authors have declared that no competing interest exists.

\section{Author's contributions}

All authors contributed equally to this work.

\section{Funding information}

This research received no specific grant from any funding agency in the public, commercial or not-for-profit sectors.

\section{Data availability statement}

Data are available from the authors at the instance of request.

\section{Disclaimer}

The views and opinions expressed in this article are those of the authors and do not necessarily reflect the official policy or position of any affiliated agency of the authors.

\section{References}

Anderson, N., Potoňik, K., \& Zhou, J. (2014). Innovation and creativity in organisations: A state-of-the-science review, prospective commentary, and guiding framework. Journal of Management, 40(5), 1297-1333. https://doi.org/10.1177/ 0149206314527128
Awang-Hashim, R., Thaliah, R., \& Kaur, A. (2017). A cultural insight into the development of teacher autonomy support scale: A self-determination theory perspective. Journal for Multicultural Education, 11(4), 36-50. https://doi. org/10.1108/JME-09-2016-0050

Bakker, A.B., \& Xanthopoulou, D. (2013). Creativity and charisma among female leaders: The role of resources and work engagement. The International Journal of Human Resource Management, 24(14), 2760-2779. https://doi.org/10.1080/095 85192.2012.751438

Bass, B.M., \& Avolio, B.J. (1995). Multifactor leadership questionnaire. Redwood City, CA: Mind Garden.

Bednall, T.C., Rafferty, A.E., Shipton, H., Sanders, K., \& Jackson, C. (2018). Innovative behaviour: How much transformational leadership do you need? British Journal of Management, 29(4), 796-816. https://doi.org/10.1111/1467-8551.12275

Berkovich, I., \& Bogler, R. (2019). The relationship between school leadership standards and school administration imperatives: An international perspective. School Leadership \& Management, 40(4), 1-14. https://doi.org/10.1080/136324 34.2019 .1682538

Blase, J., \& Blase, J. (2000). Effective instructional leadership: Teachers' perspectives on how principals promote teaching and learning in schools. Journal of Educationa Administration, 38(2), 130-141. https://doi.org/10.1108/09578230010320082

Bolino, M.C., Turnley, W.H., \& Anderson, H.J. (2016). The dark side of proactive behaviour: When being proactive may hurt oneself, others, or the organization. In Proactivity at work (pp. 517-547). Abingdon: Routledge.

Bramwell, G., Reilly, R.C., Lilly, F.R., Kronish, N., \& Chennabathni, R. (2011). Creative teachers. Roeper Review, 33(4), 228-238. https://doi.org/10.1080/02783193.201 1.603111

Burns, W.R.T., \& DiPaola, M.F. (2013). A study of organisational justice, organisational citizenship behaviour, and student achievement in high schools. American Secondary Education, 42(1), 4-23.

Chiok Foong Loke, J. (2001). Leadership behaviours: Effects on job satisfaction, productivity and organizational commitment. Journal of nursing management 9(4), 191-204. https://doi.org/10.1046/j.1365-2834.2001.00231.x

Chou, C.M., Shen, C.H., Hsiao, H.C., \& Shen, T.C. (2019). Factors influencing teachers' innovative teaching behaviour with information and communication technology (ICT): The mediator role of organisational innovation climate. Educational Psychology, 39(1), 65-85. https://doi.org/10.1080/01443410.2018.1520201

Cohen, J. (1992). A power primer. Psychological bulletin, 112(1), 155-159. https://doi. org/10.1037/0033-2909.112.1.155

Colquitt, J.A., Scott, B.A., Roddell, J.B., Long, D.M., Zapata, C.P., Conlon, D.E., \& Wesson, M.J. (2013). Justice at the millennium, a decade later: A meta-analytic test of social exchange and affect-based perspectives. Journal of Applied Psychology, 98(2), 199-236. https://doi.org/10.1037/a0031757

Cook, J., \& Wall, T. (1980). New work attitude measures of trust, organisational commitment and personal need non-fulfilment. Journal of Occupational Psychology, 53(1), 39-52. https://doi.org/10.1111/j.2044-8325.1980.tb00005.x

Daly, S.R., Mosyjowski, E.A., \& Seifert, C.M. (2019). Teaching creative process across disciplines. The Journal of Creative Behavior, 53(1), 5-17. https://doi.org/10.1002/ jocb.158

Dash, S.S., \& Vohra, N. (2019). The leadership of the school principal: Impact on teachers' job crafting, alienation and commitment. Management Research Review, 42(3), 352-369. https://doi.org/10.1108/MRR-11-2017-0384

De Jong, J., \& Hartog, D. (2010). Measuring innovative work behaviour. Creativity and Innovation Management, 19(1), 23-36. https://doi.org/10.1111/j.14678691.2010.00547.x

Deci, E.L., \& Ryan, R.M. (1985). Intrinsic motivation and self-determination in human behaviour. New York, NY: Plenum.

Dima, A., Begu, L., Vasilescu, M., \& Maassen, M. (2018). The relationship between the knowledge economy and global competitiveness in the European Union. Sustainability, 10(6), 1706. https://doi.org/10.3390/su10061706

DiPaola, M.F., \& Tschannen-Moran, M. (2001). Organizational citizenship behavior in schools and its relationship to school climate. Journal of School Leadership, 11, 424-447. https://doi.org/10.1177/105268460101100503

Ghani, N.A.A., Hussin, T.A.B.S.R., \& Jusoff, K. (2009). The Impact of psychological empowerment on lecturers' innovative behaviour in Malaysian Private Higher Education Institutions. Canadian Social Science, 5(4), 54-62. https://doi. org/10.3968/J.CSS.1923669720090504.007

Gil, A.J., Rodrigo-Moya, B., \& Morcillo-Bellido, J. (2018). The effect of leadership in the development of innovation capacity: A learning organization perspective. Leadership \& Organization Development Journal, 39(6), 694-711. https://doi. org/10.1108/LODJ-12-2017-0399

Global Competitiveness Report. (2018). The Global Competitiveness Report 2018: A project of World Economic Forum. In K. Schwab (Ed.). Geneva: World Economic Forum. Retrieved from http://www3.weforum.org/docs/GCR2018/05FullReport/ TheGlobalCompetitivenessReport2018.pdf

Gumusluoglu, L., \& Ilsev, A. (2009). Transformational leadership, creativity, and organizational innovation. Journal of Business Research, 62(4), 461-473. https:// doi.org/10.1016/j.jbusres.2007.07.032

Gupta, V., \& Singh, S. (2015). Leadership and creative performance behaviors in R\&D laboratories: Examining the mediating role of justice perceptions. Journa of Leadership \& Organizational Studies, 22(1), 21-36. https://doi.org/ $10.1177 \% 2$ F1548051813517002

Henning, J.E., Mckeny, T., Weade, G., Dani, D.E., Rice, L.J., \& Xenos, A.J. (2018). Designing teaching practice: A case study of pro-creativity. Teacher Education and Practice, 31(1), 81-101. 
Huang, X., Lee, J.C.K., \& Yang, X. (2019). What really counts? Investigating the effects of creative role identity and self-efficacy on teachers' attitudes towards the implementation of teaching for creativity. Teaching and Teacher Education, 84, implementation of teaching for creativity. Teaching

Hughes, D.J., Lee, A., Tian, A.W., Newman, A., \& Legood, A. (2018). Leadership, creativity, and innovation: A critical review and practical recommendations. The Leadership Quarterly, 29(5), 549-569. https://doi.org/10.1016/j.leaqua. 2018.03.001

Ismail, A., \& Mydin, A.A. (2019, March). The impact of transformational leadership and commitment on teachers' innovative behaviour. In 4th ASEAN Conference on Psychology, Counselling, and Humanities (ACPCH 2018) (pp. 426-430). Amsterdam: Atlantis Press.

Ismail, S.N., Don, Y., Husin, F., \& Khalid, R. (2018). Instructional leadership and teachers' functional competency across the 21st century learning. Internationa Journal of Instruction, 11(3), 135-152. https://doi.org/10.12973/iji.2018.11310a

Janssen, O. (2000). Job demands, perceptions of effort-reward fairness and innovative work behaviour. Journal of Occupational and Organisational Psychology, 73(3) 287-302. https://doi.org/10.1348/096317900167038

Janssen, O. (2004). How fairness perceptions make innovative behaviour more or less stressful. Organisational Behaviour Journal, 25(2), 201-215. https://doi. org/10.1002/job.238

Jensen, U.T., Andersen, L.B., Bro, L.L., Bøllingtoft, A., Eriksen, T.L.M., Holten, A.L., .. Westergård-Nielsen, N.' (2019). Conceptualizing and measuring transformational and transactional leadership. Administration \& Society, 51(1), 3-33. https://doi. org/10.1177\%2F0095399716667157

Jiang, L., \& Johnson, M.J. (2018). Meaningful work and affective commitment: A moderated mediation model of positive work reflection and work centrality. Journal of Business and Psychology, 33(4), 545-558. https://doi.org/10.1007/ s10869-017-9509-6

Kabasheva, I.A., Rudaleva, I.A., Bulnina, I.S., \& Askhatova, L.I. (2015). Organizational factors affecting employee innovative behavior. Mediterranean Journal of Socia Sciences, 6(1 Suppl 3), 435. https://doi.org/10.5901/mjss.2015.v6n1s3p435

Kaufman, B.E. (2015). Theorizing determinants of employee voice: An integrative model across disciplines and levels of analysis. Human Resource Management Journal, 25(1), 19-40. https://doi.org/10.1111/1748-8583.12056

Khaola, P., \& Coldwell, D. (2017a). Striking a balance between organisationa citizenship behaviour types. Southern African Business Review, 21(1), 222-242.

Khaola, P., \& Coldwell, D. (2017b, March 16-17). The effects of leadership, organisational justice and commitment on employee innovative behaviours. In Proceedings of the 5th International Conference on Management, Leadership and Governance (pp. 222-229). Johannesburg: Wits Business School.

Khaola, P., \& Coldwell, D. (2019a). Explaining how leadership and justice influence innovative behaviours. European Journal of Innovation Management, 22(1), 193innovative behaviours. European Journal of Innov

Khaola, P., \& Coldwell, D. (2019b). Please lead me, my commitment is low': Interactive effects of leadership and commitment on innovative behaviour. International Journal of Innovation Management, 23(2), 1-19. https://doi.org/10.1142/ Journal of Innovation

Khaola, P., \& Rambe, P. (2020). The effects of transformational leadership on organisational citizenship behaviour: The role of organisational justice and affective commitment. Management Research Review. https://doi.org/10.1108/ MRR-07-2019-0323

Khazanchi, S., \& Masterson, S. (2011). Who and what is fair matters: A multi-foci social exchange model of creativity. Journal of Organisational Behaviour, 32(1), 86-106. https://doi.org/10.1002/job.682

Klaeijsen, A., Vermeulen, M., \& Martens, R. (2017). Teachers' innovative behaviour: The importance of basic psychological need satisfaction, intrinsic motivation, and occupational self-efficacy. Scandinavian Journal of Educational Research, 62(5), 19-39. https://doi.org/10.1080/00313831.2017.1306803

Liu, F., Chow, I.H.S., Zhang, J.C., \& Huang, M. (2019). Organizational innovation climate and individual innovative behavior: Exploring the moderating effects of psychological ownership and psychological empowerment. Review of Manageria Science, 13(4), 771-789. https://doi.org/10.1007/s11846-017-0263-y

Liu, Y., (2019). From the viewpoint of organizational support to discuss the effect of psychological capital on innovative behavior. Argos, 36(73), 128-139.

Lu, S., Bartol, K.M., Venkataramani, V., Zheng, X., \& Liu, X. (2019). Pitching novel ideas to the boss: The interactive effects of employees' idea enactment and influence tactics on creativity assessment and implementation. Academy of Management Journal, 62(2), 579-606. https://doi.org/10.5465/amj.2016.0942

Lubienski, C., \& Perry, L. (2019). The third sector and innovation: Competitive strategies, incentives, and impediments to change. Journal of Educational Administration, 57(4), 329-344. https://doi.org/10.1108/JEA-10-2018-0193

Marinova, S.V., Peng, C., Lorinkova, N., Van Dyne, L., \& Chiaburu, D. (2015). Changeoriented behaviour: A meta-analysis of individual and job design predictors. Journal of Vocational Behaviour, 88, 104-105. https://doi.org/10.1016/j.jvb.2015.02.006

Marks, H.M., \& Printy, S.M. (2003). Principal leadership and school performance: An AdministrationQuarterly,39(3),370-397.https://doi.org/10.1177/0013161X03253412
Mercurio, Z.A. (2015). Affective commitment as a core essence of organizational commitment: An integrative literature review. Human Resource Development Review, 14(4), 389-414. https://doi.org/10.1177\%2F1534484315603612

Meyer, J.P., \& Allen, N.J. (1991). A three-component conceptualization of organizational commitment. Human Resource Management Review, 1(1), 61-89. https://doi. org/10.1016/1053-4822(91)90011-Z

Meyer, J.P., Morin, A.J.S., Stanley, L.J., \& Maltin, E.R. (2019). Teachers' dual commitment to the organisation and occupation: A person-centred investigation. Teaching and Teacher Education, 77, 100-111. https://doi.org/10.1016/j. tate.2018.09.009

Ministry of Education and Training (MoET). (2014). Curriculum and assessment policy: Education for individual and social development. Maseru: Author.

Mumford, M.D., \& Licuanan, B. (2004). Leading for innovation: Conclusions, issues, and directions. The Leadership Quarterly, 15(1), 163-171. https://doi. org/10.1016/j.leaqua.2003.12.010

Nava, I., Park, J., Dockterman, D., Kawasaki, J., Schweig, J., Quartz, K.H., \& Martinez, J.F. (2019). Measuring teaching quality of secondary mathematics and science
residents: A classroom observation framework. Journal of Teacher Education, residents: A classroom observation framework. Journal of Teach

Niehoff, B.P., \& Moorman, R.H. (1993). Justice as a mediator of the relationship between methods of monitoring and organizational citizenship behavior. Academy of Management Journal, 36(3), 527-556. https://doi.org/10.2307/256591

Ninković, S.R., \& Knežević Florić, O.Č. (2018). Transformational school leadership and teacher self-efficacy as predictors of perceived collective teacher efficacy. Educational Management Administration \& Leadership, 46(1), 49-64. https://doi. org/10.1177/1741143216665842

O'Connor, K.E. (2008). 'You choose to care': Teachers, emotions and professional identity. Teaching and Teacher Education, 24(1), 117-126. https://doi. org/10.1016/j.tate.2006.11.008

Oh, S.Y. (2019). Effects of organizational learning on performance: The moderating roles of trust in leaders and organizational justice. Journal of Knowledge Management, 23(2), 313-331. https://doi.org/10.1108/JKM-02-2018-0087

Rank, J., Nelson, N.E., Allen, T.D., \& Xu, X. (2009). Leadership predictors of innovation and task performance: Subordinates' self-esteem and self-presentation as moderators. Journal of Occupational and Organisational Psychology, 82(3), 465-489. https://doi. org/10.1348/096317908X371547

Raselimo, M., \& Mahao, M. (2015). The Lesotho curriculum and assessment policy: Opportunities and threats. South African Journal of Education, 35(1), 1-12. https://doi.org/10.15700/201503070025

Reilly, R.C., Lilly, F., Bramwell, G., \& Kronish, N. (2011). A synthesis of research concerning creative teachers in a Canadian context. Teaching and Teacher Education, 27(3), 533-542. https://doi.org/10.1016/j.tate.2010.10.007

Saboe, K.N., Taing, M.U., Way, J.D., \& Johnson, R.E. (2015). Examining the unique mediators that underlie the effects of different dimensions of transformational mediators that underlie the effects of different dimensions of transformational leadership. Journal of Leadership \& Organiza
$\mathrm{https} / / /$ doi.org/10.1177/1548051814561028

Scott, S.G., \& Bruce, R.A. (1994). Determinants of innovative work behaviour: A path model of individual innovation in the workplace. Academy of Management Journal, 37(3), 580-607. https://doi.org/10.2307/256701

Somech, A. (2016). The cost of going the extra mile: The relationship between teachers' organizational citizenship behaviour, role stressors, and strain with the buffering effect of job autonomy. Teachers and Teaching, 22(4), 426-447. https:// doi.org/10.1080/13540602.2015.1082734

Srivastava, A.P. (2017). Teachers' extra role behaviour: Relation with self-efficacy, procedural justice, organisational commitment and support for training. International Journal of Management in Education, 11(2), 140-162. https://doi. org/10.1504/IJMIE.2017.10002822

Srivastava, A.P., \& Dhar, R.L. (2019). Authentic leadership and extra role behavior: A school based integrated model. Current Psychology, 38(3), 684-697. https://doi. org/10.1007/s12144-017-9634-4

Stojcic, N., Hashi, I., \& Orlic, E. (2018). Creativity, innovation effectiveness and productive efficiency in the UK. European Journal of Innovation Management, 21(4), 564-580. https://doi.org/10.1108/EJIM-11-2017-0166

Torfing, J. (2019). Collaborative innovation in the public sector: The argument. Public Management Review, 21(1), 1-11. https://doi.org/10.1080/14719037.2018.1430 248

Usma, J., \& Frodden, C. (2003). Promoting teachers' autonomy through educational innovation. Ikala, Revista de lenguaje y cultura, 8(14), 101-132.

Van Knippenberg, D., \& De Cremer, D. (2008). Leadership and fairness: Taking stock and looking ahead. European Journal of Work and Organizational Psychology, 17(2), 173-179. https://doi.org/10.1080/13594320801912137

Walker, C., \& Gleaves, A. (2016). Constructing the caring higher education teacher: A theoretical framework. Teaching and Teacher Education, 54, 65-76. https://doi. org/10.1016/j.tate.2015.11.013

Zhou, J., \& Hoever, I. (2014). Research on workplace creativity: A review and redirection. Organisational Psychology and Organisational Behaviour, 1, 333-359. https://doi.org/10.1146/annurev-orgpsych-031413-091226 